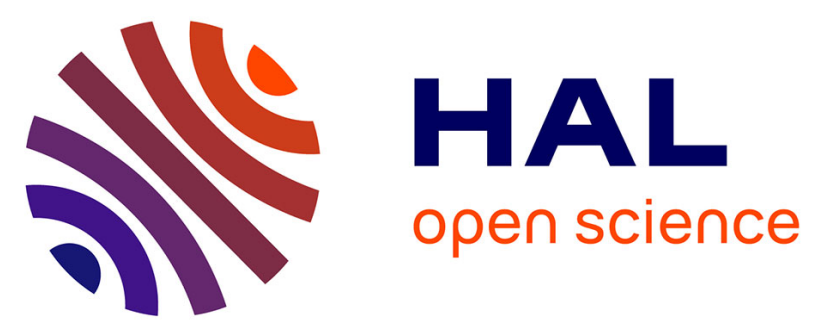

\title{
Enhanced Cardiomyocyte Ca $2+$ Cycling Precedes Terminal AV-Block in Mitochondrial Cardiomyopathy Mterf3 KO Mice
}

\author{
Daniel Andersson, J. Fauconnier, Chan Bae Park, Shi-Jin Zhang, Jérôme \\ Thireau, Niklas Ivarsson, Nils-Göran Larsson, Håkan Westerblad
}

\section{To cite this version:}

Daniel Andersson, J. Fauconnier, Chan Bae Park, Shi-Jin Zhang, Jérôme Thireau, et al.. Enhanced Cardiomyocyte Ca 2 + Cycling Precedes Terminal AV-Block in Mitochondrial Cardiomyopathy Mterf3 KO Mice. Antioxidants and Redox Signaling, 2011, 15 (9), pp.2455-2464. 10.1089/ars.2011.3915 . hal-02542081

\section{HAL Id: hal-02542081 \\ https://hal.umontpellier.fr/hal-02542081}

Submitted on 14 Apr 2020

HAL is a multi-disciplinary open access archive for the deposit and dissemination of scientific research documents, whether they are published or not. The documents may come from teaching and research institutions in France or abroad, or from public or private research centers.
L'archive ouverte pluridisciplinaire HAL, est destinée au dépôt et à la diffusion de documents scientifiques de niveau recherche, publiés ou non, émanant des établissements d'enseignement et de recherche français ou étrangers, des laboratoires publics ou privés. 


\title{
Enhanced Cardiomyocyte $\mathrm{Ca}^{2+}$ Cycling Precedes Terminal AV-Block in Mitochondrial Cardiomyopathy Mterf3 KO Mice
}

\author{
Daniel C. Andersson,,* Jérémy Fauconnier, ${ }^{2}$ Chan Bae Park, ${ }^{3, \dagger}$ Shi-Jin Zhang, \\ Jerôme Thireau, ${ }^{2}$ Niklas Ivarsson, Nils-Göran Larsson, ${ }^{3,+}$ and Håkan Westerblad ${ }^{1}$
}

\begin{abstract}
Aims: Heart disease is commonly associated with altered mitochondrial function and signs of oxidative stress. This study elucidates whether primary cardiac mitochondrial dysfunction causes changes in cardiomyocyte handling of reactive oxygen species (ROS) and $\mathrm{Ca}^{2+}$. We used a mouse model with a tissue-specific ablation of the recently discovered mtDNA transcription regulator Mterf3 (Mterf3 KO). These mice display a cardiomyopathy with severe respiratory chain dysfunction, cardiac hypertrophy, and shortened lifespan. ROS and Ca ${ }^{2+}$ handling were measured using fluorescent indicators and confocal microscopy. Results: Mterf3 KO hearts displayed no signs of increased ROS production or oxidative stress. Surprisingly, Mterf3 KO cardiomyocytes showed enlarged $\mathrm{Ca}^{2+}$ transient amplitudes, faster sarcoplasmic reticulum (SR) $\mathrm{Ca}^{2+}$ reuptake, and increased SR $\mathrm{Ca}^{2+}$ load, resembling increased adrenergic stimulation. Furthermore, spontaneous releases of $\mathrm{Ca}^{2+}$ were frequent in Mterf3 KO cardiomyocytes. Electrocardiography (measured with telemetry in freely moving mice) showed a terminal state in Mterf3 $\mathrm{KO}$ mice with gradually developing bradycardia and atrioventricular block. Conclusion: In conclusion, mitochondrial dysfunction induced by Mterf3 KO leads to a cardiomyopathy without signs of oxidative stress but with increased cardiomyocyte $\mathrm{Ca}^{2+}$ cycling and an arrhythmogenic phenotype. These findings highlight the complex interaction between mitochondrial function, cardiomyocyte contractility, and compensatory mechanisms, such as activation of adrenergic signaling.
\end{abstract}

\section{Introduction}

$\mathbf{P}$ RIMARY MITOCHONDRIAL DISEASES are characterized by defective cellular respiration and are typically caused by mutations in genes encoding for proteins in the respiratory chain (22). The proteins of the mitochondrial respiratory chain are transcribed by genes from both the nuclear DNA and the mitochondrial DNA (mtDNA). Moreover, all transcription factors for the mitochondrial genome are encoded in the nucleus. Thus, respiratory chain function is dependent on a complex interplay between mitochondrial and nuclear genomes (38). Tissues with high energy demand (e.g., brain, cardiac and skeletal muscle) are commonly affected in mitochondrial disease (33). Cardiac involvement in mitochondrial disease can be manifested both as dilated and hypertrophic cardiomyopathy, often in conjunction with rhythm distur- bances, such as atrioventricular conduction block (AV-block) (22). Moreover, mitochondrial dysfunction is implicated in the mechanisms of heart failure in general $(26,47)$. It has been suggested that the respiratory chain dysfunction in mitochondrial diseases leads to increased production of reactive oxygen species (ROS) and oxidative stress (13).

Transcription of $\mathrm{mtDNA}$ is controlled by proteins encoded in the nucleus that are imported into the mitochondria, for example, mitochondrial RNA polymerase (POLRMT), mitochondrial transcription factor A (Tfam), and mitochondrial transcription factor B1 (TFB1M) and B2 (TFB2M). Recently, a new regulatory protein of mammalian mtDNA transcription was described, the mitochondrial transcription termination factor 3 (MTERF3) (31). MTERF3 works by repressing initiation of mtDNA transcription and is the first specific negative regulator of mtDNA transcription to be described.

\footnotetext{
${ }^{1}$ Department of Physiology and Pharmacology, Karolinska Institutet, Stockholm, Sweden. Most of the work was done in this department

${ }^{2}$ INSERM U1064, Université Montpellier 1; Université Montpellier 2, Montpellier, France.

${ }^{3}$ Department of Laboratory Medicine, Karolinska Institutet, Stockholm, Sweden.

*Current affiliation: Department of Physiology and Cellular Biophysics, Columbia University, New York, New York.

Current affiliation: Institute for Medical Sciences, Ajou University School of Medicine, Suwon, Korea.

Current affiliation: Max Planck Institute for Biology of Ageing, Cologne, Germany.
} 


\section{Innovation}

Heart disease is commonly associated with altered mitochondrial function. To study the link between defective mitochondria and cardiac dysfunction, a genetically engineered mouse model was used that displays severe respiratory chain dysfunction in cardiomyocytes, musclespecific Mterf3 KO mice. Mterf3 KO cardiomyocytes showed no signs of oxidative stress, sarcoplasmic reticulum $\mathrm{Ca}^{2+}$ overload and an increased number of spontaneous $\mathrm{Ca}^{2+}$ release-events, reduced heart rate variability indicating increased sympathetic drive, and terminal progressive bradycardia ending with a complete atrioventricular conduction block. These findings highlight the complex interaction between mitochondrial function, cardiomyocyte contractility, and compensatory mechanisms such as activation of adrenergic signaling. The results support a central role of mitochondria in the early phase of cardiomyopathic disease, characterized by activation of adrenergic signaling and elevated risk of premature death.

Cardiac contractility critically depends on tightly controlled fluxes of $\mathrm{Ca}^{2+}$ within the cardiomyocyte. Disturbances in the $\mathrm{Ca}^{2+}$ handling can underlie pathological conditions such as heart failure and cardiac arrhythmias (5). In cardiomyocytes of end-stage cardiomyopathy and heart failure, action potential-triggered $\mathrm{Ca}^{2+}$ release from the sarcoplasmic reticulum (SR) into the cytoplasm is reduced and the reuptake of $\mathrm{Ca}^{2+}$ into the SR is slowed (16). Thus, in failing cardiomyocytes, the SR $\mathrm{Ca}^{2+}$ cycling process is depressed, leading to reduced contractility. The inotropic response to $\beta$-adrenergic stimulation in the end-stage cardiomyopathy is typically blunted (6) due to downregulation of mediators in the $\beta$ adrenoreceptor signaling cascade (49). However, cardiomyocytes from hypertrophic hearts have been shown to have preserved responsiveness to $\beta$-adrenergic stimulation (23).
This suggests that in the cardiomyopathy progress, before the disease enters a fulminant heart failure, there is a point where reduced cardiac contractility can be compensated by increased sympathetic drive.

We have studied a new mouse model of primary mitochondrial cardiomyopathy where the Mterf3 gene was ablated specifically in cardiac and skeletal muscle. Mice with Mterf3 ablation (Mterf3 $\mathrm{KO}$ ) display a defective mtDNA transcription. This causes dramatically decreased activity in respiratory chain complexes and a consequent decline in mitochondrial ATP production rate from $\sim 12$ weeks age (31). Moreover, the mitochondria Mterf3 $\mathrm{KO}$ mice show a disfigured appearance and the relative mitochondrial mass is markedly increased in $>12$ weeks old Mterf3 $\mathrm{KO}$ compared to control mice (31). These findings are consistent with what is seen in biopsy specimens from patients with mitochondrial cardiomyopathy (22). Furthermore, Mterf3 KO mice develop cardiac hypertrophy and have a maximal lifespan of only 18 weeks (31). No pathological phenotype is observed in skeletal muscles of the Mterf3 $\mathrm{KO}$ mice $(3,31)$.

In the present study, we used the Mterf3 $\mathrm{KO}$ model to investigate cardiomyocyte $\mathrm{ROS}$ production, $\mathrm{Ca}^{2+}$ signaling, and contractility associated with primary mitochondrial dysfunction. We used hearts from $>12$-week-old mice, where major changes in mitochondrial function is observed in Mterf3 $\mathrm{KO}$ mice. Surprisingly, cardiomyocytes of Mterf3 KO mice display increased SR $\mathrm{Ca}^{2+}$ load with larger amplitude and faster decay of cytoplasmic $\mathrm{Ca}^{2+}$ transients. Since these changes cannot explain the short lifespan of Mterf3 KO mice, we used telemetry to follow cardiac function with electrocardiography (ECG), body temperature, and locomotor activity for several days at the end of their expected lifetime. The results show that shortly before death, the Mterf3 KO mice display a gradually developing bradycardia and AV-block. Thus, this model of cardiomyopathy shed light on the role of mitochondrial dysfunction in the complex mechanisms of cardiac arrhythmias and cardiomyopathy.
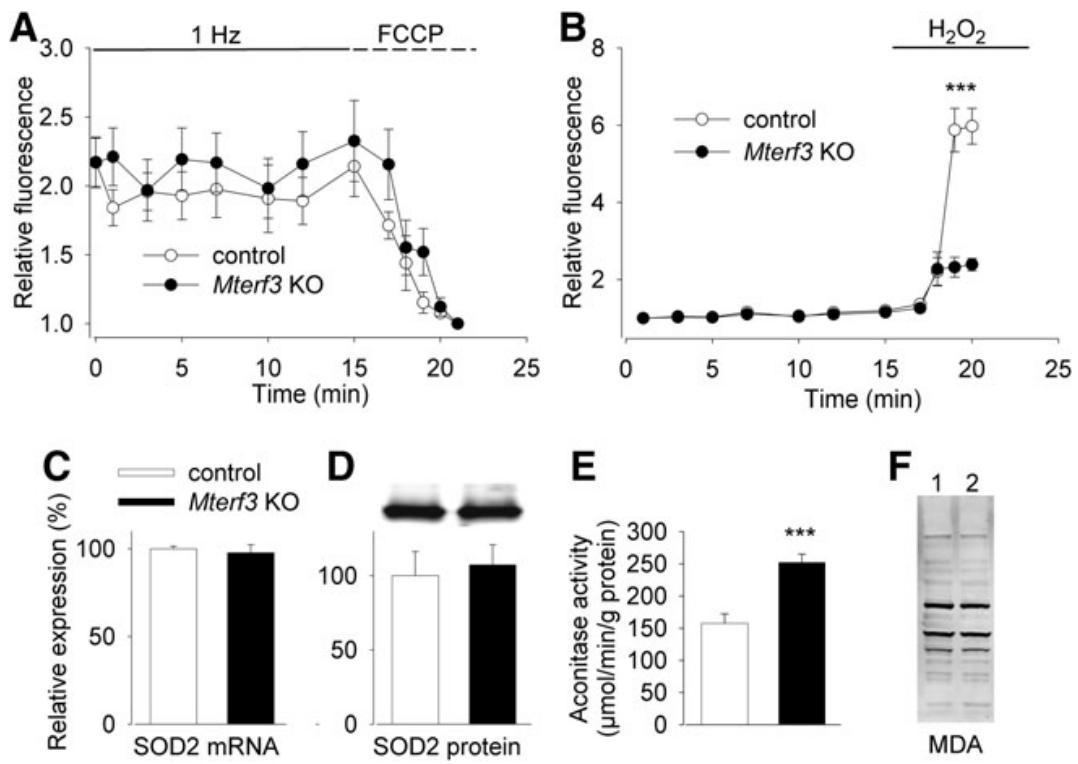

FIG. 1. Signs of reduced ROS production in Mterf3 $\mathrm{KO}$ hearts. (A) Mitochondrial membrane potential $\left(\Delta \Psi_{\mathrm{m}}\right)$ during $1 \mathrm{~Hz}$ stimulation and in the presence of the depolarizing agent FCCP (relative fluorescence normalized to the maximal depolarizing effect of FCCP; control, $n=12$ cells from 2 mice; Mterf3 $\mathrm{KO}, n=15$ cells from 2 mice). (B) Change in MitoSOX Red fluorescence on $1 \mathrm{~Hz}$ stimulation and under product inhibition of SOD with $\mathrm{H}_{2} \mathrm{O}_{2}$ (control, $n=12$ cells from 2 animals, Mterf3 KO, $n=7$ cells from 2 animals). (C) mRNA expression of SOD2 in the control $(n=3)$ and Mterf3 KO $(n=3)$ hearts. Mean value in control set to $100 \%$. (D) Protein expression of SOD2 in control $(n=3)$ and Mterf3 KO $(n=4)$ hearts. Measurements normalized to protein content and the mean value in control set to $100 \%$. Representative blots shown above bars. (E) Aconitase activity normalized to the sample protein content in control $(n=5)$ and Mterf3 $\mathrm{KO}(n=7)$

hearts; ${ }^{* * *} p<0.001$. (F) Representative Western blot of total MDA protein adducts in control (lane 1) and Mterf3 KO (lane 2) heart. Similar results were obtained in three more hearts of each group. 


\section{Results}

\section{No signs of mitochondrial membrane depolarization} or oxidative stress in Mterf3 $\mathrm{KO}$

Mterf3 KO mice display severely defective cardiac respiratory chain function and reduced mitochondrial ATP production rate (31). This prompted us to investigate whether the mitochondrial membrane potential $\left(\Delta \Psi_{\mathrm{m}}\right)$ was altered in the Mterf3 $\mathrm{KO}$ mouse. We used intact cardiomyocytes loaded with the membrane permeable fluorescent indicator TMRE that accumulates in the mitochondria in a $\Delta \Psi_{\mathrm{m}}$-dependent manner. No difference in $\Delta \Psi_{\mathrm{m}}$ was found between Mterf3 $\mathrm{KO}$ and control cardiomyocytes either during $1 \mathrm{~Hz}$ stimulation under control conditions or in the presence of the depolarizing agent FCCP (Fig. 1A). We also measured mitochondrial $\mathrm{O}_{2}{ }^{*}$ production in Mterf3 KO cardiomyocytes. Freshly isolated cardiomyocytes were loaded with the $\mathrm{O}_{2}{ }^{*}$ specific indicator MitoSOX Red and paced at $1 \mathrm{~Hz}$. The MitoSOX Red signal was not changed during the stimulation period in either control or Mterf3 KO (Fig. 1B). To assess the mitochondrial capacity of $\mathrm{O}_{2}{ }^{*-}$ production, we exposed the cells to $1 \mathrm{mM}$ of $\mathrm{H}_{2} \mathrm{O}_{2}$, which would induce product inhibition of the SOD2 and thereby restrain the conversion of $\mathrm{O}_{2}{ }^{*}$ to $\mathrm{H}_{2} \mathrm{O}_{2}(3,17,29)$. This resulted in large increases in MitoSOX Red fluorescence in the control cardiomyocytes, whereas this increase was considerably smaller in the Mterf3 $\mathrm{KO}$ cells (Fig. 1B).

The expression of SOD2 can be altered under conditions of oxidative stress (40). However, neither mRNA nor protein expression of SOD2 differed between Mterf3 $\mathrm{KO}$ and control hearts (Figs. 1C and 1D). We also measured the activity of the mitochondrial enzyme aconitase, which may decrease in oxidative stress (15). Interestingly, there was a significant increase in aconitase activity in the Mterf3 $\mathrm{KO}$ heart compared to control, both when normalized to total protein (Fig. $1 \mathrm{E})$ or to the mitochondrial mass (measured as citrate synthase activity; Mterf3 KO, $62 \pm 2.1$ vs. control, $53 \pm 2.1$ (mU/ $\mathrm{U}), p<0.05)$. Increased ROS production is associated with decomposition of polyunsaturated fatty acids, which leads to the formation of reactive carbonyl species that can bind to protein (1). We used Western blotting and an antibody specific for protein binding of one such carbonyl species, malondialdehyde (MDA), and observed no difference between Mterf3 KO and control hearts (Fig. 1F). Taken together, we found no evidence of oxidative stress in the Mterf3 $\mathrm{KO}$ heart. Conversely, there were actually signs of reduced ROS production in the mitochondria of Mterf $\mathrm{KO}$ hearts.

\section{Increased SR $\mathrm{Ca}^{2+}$ cycling in Mterf3 cardiomyocytes}

Altered cellular $\mathrm{Ca}^{2+}$ handling is a central feature in cardiomyocytes from failing hearts. Cardiomyocytes from $\sim 14$ week-old control and MTERF3 KO mice were used to measure action potential-induced $\mathrm{Ca}^{2+}$ transients and cardiac cell shortening. Interestingly, $\mathrm{Ca}^{2+}$ transient amplitudes were notably larger in Mterf3 $\mathrm{KO}$ cardiomyocytes compared to control at all pacing frequencies (Figs. $2 \mathrm{~A}$ and 2B). Furthermore, the $\mathrm{Ca}^{2+}$ transient decay was faster in Mterf3 $\mathrm{KO}$ cells at $0.5-1 \mathrm{~Hz}$ stimulation, as shown by a lower decay time constant $(\tau)$ (Fig. 2C). Application of $100 \mathrm{nM}$ of the $\beta$-adrenergic agonist isoproterenol (ISO), together with $1 \mathrm{~Hz}$ stimulation, made $\mathrm{Ca}^{2+}$ transients larger and faster and the difference between control and Mterf3 $\mathrm{KO}$ cardiomyocytes disappeared (Figs. 2B and 2C). An increased decay speed of the $\mathrm{Ca}^{2+}$ transient is mainly a result of enhanced $\mathrm{Ca}^{2+}$ uptake into the SR. Thus, a faster decay normally reflects an increased loading of $\mathrm{Ca}^{2+}$ into the SR. We therefore measured the SR $\mathrm{Ca}^{2+}$ load by briefly applying caffeine $(10 \mathrm{mM})$ which activates the RyR2 and fully releases the $\mathrm{SR} \mathrm{Ca}^{2+}$. As expected, the SR $\mathrm{Ca}^{2+}$ load was higher in Mterf3 $\mathrm{KO}$ than in control cardiomyocytes (Fig. 2D). An increased activity of the sympathetic nervous system has been associated with phosphorylation of RyR2 at Ser ${ }^{2808}$ (36). We used Western blotting to measure the relation between Ser $^{2808}$ phosphorylated and total RyR2 and observed $\sim 25 \%$ higher degree of phosphorylation in Mterf3 KO than in control hearts (Fig. 2E).
FIG. 2. Cardiomyocyte $\mathrm{Ca}^{2+}$ cycling and contractility are enhanced in Mterf3 KO. (A) Typical examples of cardiomyocyte $\mathrm{Ca}^{2+}$ transients in Mterf3 $\mathrm{KO}$ and control at $1 \mathrm{~Hz}$ stimulation. Average data $\left( \pm\right.$ SEM) of $\mathrm{Ca}^{2+}$ transient amplitudes (B) and decay time constant $(\mathbf{C})$ at $0.5 \mathrm{~Hz}$, $1 \mathrm{~Hz}$, and $3 \mathrm{~Hz}$ stimulation and in the presence of ISO $(100 \mathrm{nM})$, respectively ( $n \geq 16$ cells from 3 mice in all groups). (D) Amplitude of the caffeine $(10 \mathrm{mM})$ triggered $\mathrm{Ca}^{2+}$ transient. (E) The relation of RyR2 phosphorylated at $\operatorname{Ser}^{2808}\left(\mathrm{pS}^{2808}\right)$ to total RyR2; average data from 3 control and 4 Mterf3 $\mathrm{KO}$ hearts. Representative blots are shown above bars. (F) Cardiomyocyte size measured in confocal images. Average width and length of control cardiomyocytes set to $100 \%$. Data from $\geq 21$ cells from 3 mice. (G) Contractility measured as fractional shortening in percent of the resting cardiac cell length (FS \%) at $0.5,1$, and $3 \mathrm{~Hz}$ stimulation and in the presence of ISO. ${ }^{*} p<0.05$, *** $p<0.001$.
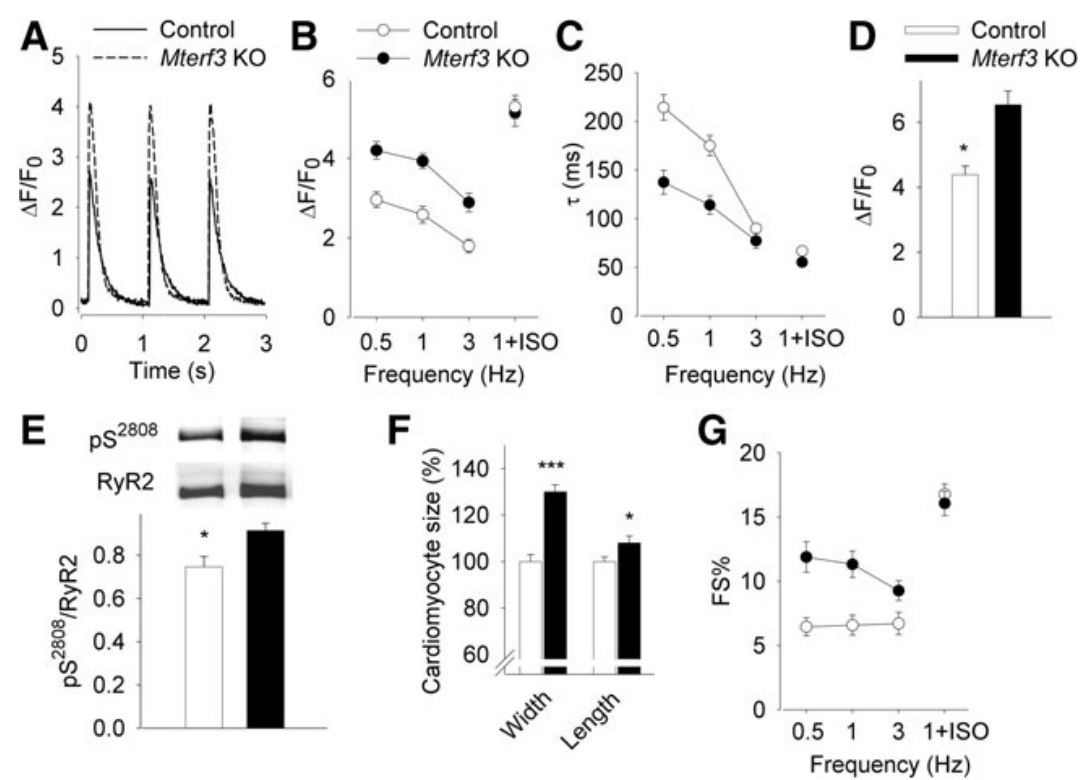


\section{Increased contractility and cell size in Mterf3 KO cardiomyocytes}

The size of cardiomyocytes was measured in confocal images. Consistent with a cardiac hypertrophy phenotype, the cardiomyocyte diameter and length were $\sim 30 \%$ and $\sim 10 \%$ larger in Mterf3 $\mathrm{KO}$ as compared to control (Fig. 2F).

Contractility was assessed by measuring fractional shortening (FS\%) of the cardiomyocytes. Mterf3 KO cardiomyocytes displayed increased $\mathrm{FS} \%$ relative to control when paced at $0.5-3 \mathrm{~Hz}$ but not in the presence of ISO (Fig. 2G). Using the same cells as for the contractility measurements, cardiac cell size (measured as the length of the cardiomyocyte long axis) was investigated.

\section{Spontaneous $\mathrm{Ca}^{2+}$ release in Mterf3 $\mathrm{KO}$}

Spontaneous $\mathrm{Ca}^{2+}$ release events (either in the form of spontaneously activated "aberrant" $\mathrm{Ca}^{2+}$ transients as in Fig. $3 \mathrm{~A}$ or scattered localized $\mathrm{Ca}^{2+}$ releases as in Fig. 3B) were more prevalent in Mterf3 $\mathrm{KO}$ cardiomyocytes than in control. When paced at 0.5 or $1 \mathrm{~Hz}, \sim 13 \%$ (3 out of 23 cells, from 3 mice) and $\sim 15 \%$ ( 5 out of 34 cells, from 3 mice), respectively, of the Mterf 3
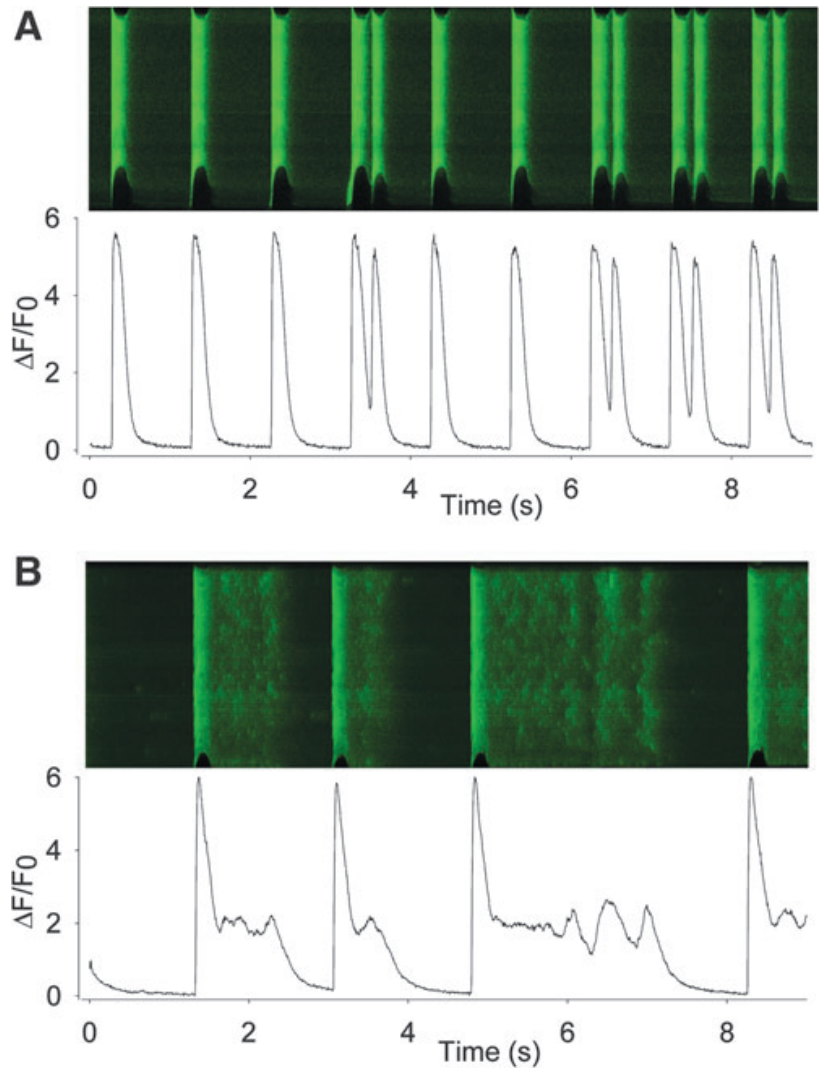

FIG. 3. Spontaneous $\mathrm{Ca}^{2+}$ release events in Mterf3 $\mathrm{KO}$ cardiomyocytes. Pseudocolor line scans and fluorescence intensity graphs from Mterf3 $\mathrm{KO}$ displaying aberrant $\mathrm{Ca}^{2+}$ release events: (A) doublet $\mathrm{Ca}^{2+}$ transients after ISO exposure (the cell was paced at $1 \mathrm{~Hz}$ ); (B) spontaneous $\mathrm{Ca}^{2+}$ release events at $1 \mathrm{~Hz}$ stimulation without ISO. Note that in $\mathbf{B}$, pacing-induced $\mathrm{Ca}^{2+}$ transients were intermittently absent in the presence of spontaneous $\mathrm{Ca}^{2+}$ release events. (To see this illustration in color the reader is referred to the web version of this article at www.liebertonline.com/ars).
KO cardiomyocytes displayed spontaneous $\mathrm{Ca}^{2+}$ release events. In control cardiomyocytes, such events occurred in no cells ( 0 out of 33 , from 3 mice) during $0.5 \mathrm{~Hz}$ pacing and in $\sim 7$ $\%$ of the cells ( 2 out of 30 cells, from 3 mice) during $1 \mathrm{~Hz}$ pacing. When cells were stressed by applying ISO, $\sim 43 \%$ (23 out of 53 cells, from 3 mice) of the Mterf3 $\mathrm{KO}$ cardiomyocytes displayed spontaneous $\mathrm{Ca}^{2+}$ events as compared to only $\sim 18 \%$ (7 out of 40 cells, from 3 mice) in the control group.

\section{Reduced heart rate variability and progressive AV-block in Mterf3 KO}

To capture changes in whole heart function, we performed long-term ECG measurements. Two phases were discerned in the Mterf3 $\mathrm{KO}$ mice, a moribund stage, starting around 24 hours prior to the endpoint and a pre-moribund stage $>24$ hours before the endpoint (Figs. 4 and 5). In the pre-moribund stage, the Mterf3 KO mice displayed similar R-R, P-R, and QRS times compared to control. On the other hand, the heart rate variability was lower in the Mterf $3 \mathrm{KO}$ than in the control $(p<0.001$; Fig. 4D). Spectral analysis of the Mterf3 KO heart rate variability in the pre-moribund stage revealed a diminished low frequency (LF) power density and a slightly increased high frequency (HF) power density compared to control (Fig. 4E). Thus, the quotient between LF and HF (LF/ HF) was substantially decreased (Fig. 4E).

Towards the end of the lifespan of Mterf3 $\mathrm{KO}$ mice, we noted a gradually developing bradycardia with increasing $\mathrm{R}$ $\mathrm{R}, \mathrm{P}-\mathrm{R}$, and QRS times (Figs. 4A-4C). The original ECG records in Figure 5 show increasing AV conduction times in Mterf3 KO mice, which developed into a complete AV-block 30 min before the endpoint (Fig. 5D). Furthermore, at the start of the moribund stage, we noted a progressive decline in core body temperature in all the Mterf $3 \mathrm{KO}$ mice from $\sim 35^{\circ} \mathrm{C}$ to $25^{\circ} \mathrm{C}$. Also, locomotor activity in the Mterf3 $\mathrm{KO}$ was reduced by $\sim 75 \%$ compared to the control.

\section{Discussion}

We have studied muscle-specific Mterf3 $\mathrm{KO}$ mice, a model of mitochondrial cardiomyopathy with a partly unexpected phenotype consisting of: 1) no signs of increased mitochondrial ROS production or oxidative stress; 2 ) SR $\mathrm{Ca}^{2+}$ overload and enhanced cellular $\mathrm{Ca}^{2+}$ cycling; 3) reduced heart rate variability and collapsed low frequency spectrum indicating increased sympathetic drive; and 4) terminal progressive bradycardia ending with a complete AV-block.

Mterf3 ablation in the mouse heart leads to respiratory chain failure and increased mitochondrial mass (31), consistent with the findings in humans with mitochondrial cardiomyopathy. It has been suggested that respiratory chain dysfunction in mitochondrial diseases would lead to an increase in ROS production and oxidative stress (13). However, our results show no signs of increased ROS or oxidative stress in Mterf3 $\mathrm{KO}$ hearts. Aconitase activity decreases under oxidative stress (15) and we saw an increase in the activity in Mterf3 KO hearts. SOD2 expression has been shown to be increased in oxidative stress (40) but SOD2 mRNA and protein expression was unchanged in Mterf $3 \mathrm{KO}$ hearts. Increased ROS production is associated with increased MDA protein binding (1), but we observed no difference between Mterf3 KO and control hearts in this respect. Also, MitoSOX Red fluorescence was diminished in Mterf3 $\mathrm{KO}$ cardiomyocytes after 
FIG. 4. ECG changes in Mterf3 KO mice. ECG recordings in Mterf3 $\mathrm{KO}$ mice during 5 days prior to the endpoint (Mterf3 $\mathrm{KO}$, $n=3$; control mice followed during the same time period, $\mathrm{O}, n=3)$. R-R time (A), P-R time (B), and QRS time (C). (D) Heart rate variability, measured as the standard deviation of all normal R-R intervals (SDNN). (E) Frequency domain analysis of heart rate variability 48 hours before endpoint of Mterf3 KO. Powers of the low frequency (LF, 0.15 $1.5 \mathrm{~Hz})$, high frequency $(\mathrm{HF}, 1.5-5 \mathrm{~Hz})$ and the quotient between LF and HF (LF/HF). ${ }^{*} p<0.05,{ }^{* * *} p<0.001$.
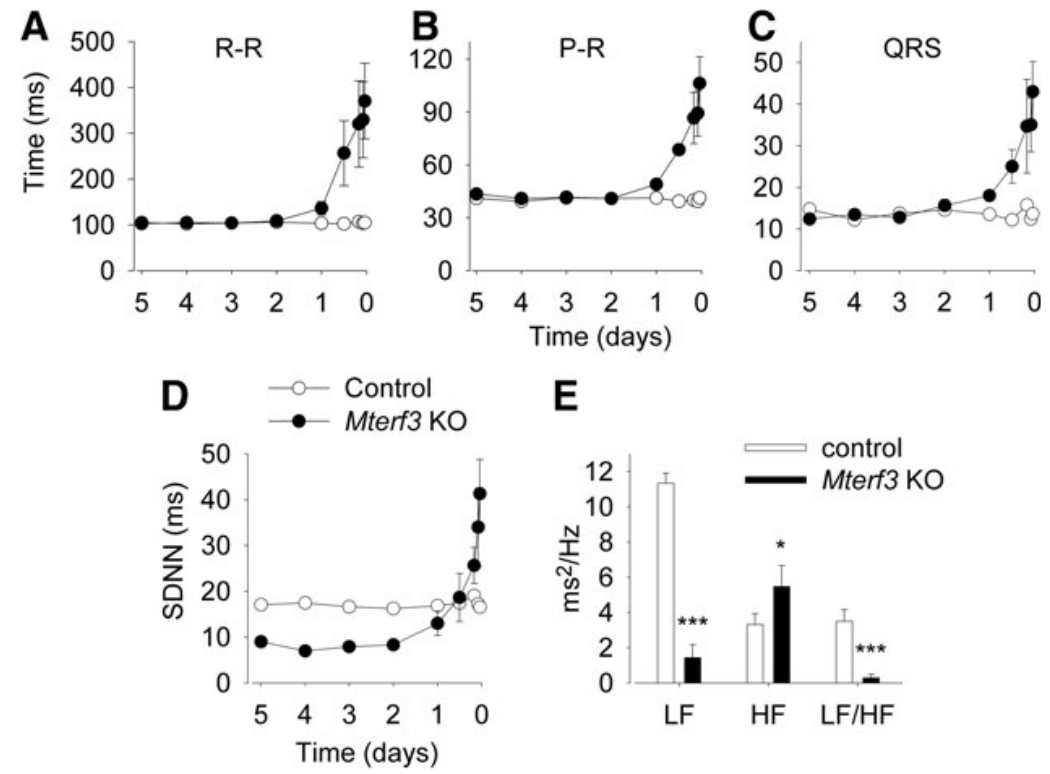

E

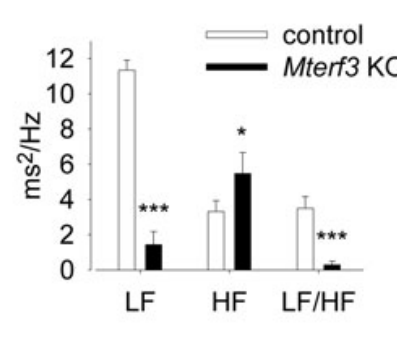

inducing product inhibition of SOD, indicating that mitochondrial $\mathrm{O}_{2}{ }^{*-}$ production was, if anything, lower in Mterf3 $\mathrm{KO}$. Reduced $\mathrm{O}_{2}{ }^{*-}$ production and absence of oxidative stress were recently shown in a different model of respiratory chain deficiency, the Tfam skeletal muscle KO (3). These results corroborate what has been found in two aging models, which develop mitochondrial respiratory chain dysfunction and fail to show an increase in ROS production or ROS induced cell damage $(21,45)$. Thus, several pieces of evidence are now accumulating against the view that mitochondrial dysfunction mandatorily leads to increased ROS production. In fact, it might be argued that impaired respiratory chain function is correlated with decreased mitochondrial ROS production based on our present and previously published findings (3).

In end-stage cardiomyopathy and heart failure, cardiomyocytes typically exhibit decreased $\mathrm{SR} \mathrm{Ca}^{2+}$ cycling properties with reduction in $\mathrm{SR} \mathrm{Ca}^{2+}$ release during systole and slowed SR $\mathrm{Ca}^{2+}$ uptake in diastole (37). Surprisingly, cardi-

A
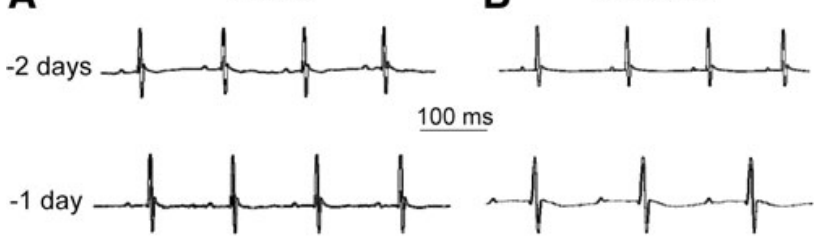

C -4 hours
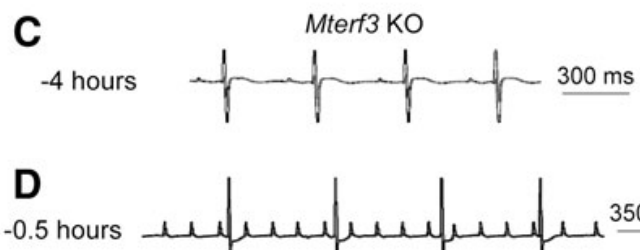

-0.5 hours

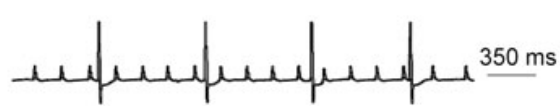

FIG. 5. Gradually developing AV-block and bradycardia in Mterf3 KO hearts. Representative ECG records from control (A) and Mterf3 $\mathrm{KO}$ mice (B-D). Times to the right of records indicate times before the endpoint. Note the different time bars in $\mathbf{A}$ and $\mathbf{B}$ compared to $\mathbf{C}$ and $\mathbf{D}$. omyocytes obtained from Mterf3 $\mathrm{KO}$ mice before the moribund stage displayed increased amplitudes and faster decay of the $\mathrm{Ca}^{2+}$ transients, along with improved contractility. Moreover, SR $\mathrm{Ca}^{2+}$ load was elevated and the extent of RyR2 $\mathrm{Ser}^{2808}$ phosphorylation was increased. These findings are in line with what is seen during $\beta$-adrenergic stimulation $(4,36)$ and the difference between Mterf $3 \mathrm{KO}$ and control cells disappeared when ISO was applied. Larger and faster $\mathrm{Ca}^{2+}$ transients and increased contractility have also been seen in cardiomyocytes of a genetic mouse model where the SRassociated protein junctin was ablated (51). Similar to Mterf3 $\mathrm{KO}$ hearts, the junctin-deficient hearts displayed elevated SR $\mathrm{Ca}^{2+}$ load compared to controls, and the difference in contractile parameters and $\mathrm{Ca}^{2+}$ transient amplitude vanished in the presence of ISO. Larger and faster $\mathrm{Ca}^{2+}$ transients, increased SR $\mathrm{Ca}^{2+}$ load, and increased contractility have also been observed in cardiomyocytes from a mouse model of early congestive heart failure following myocardial infarction (30). Thus, an initial phase, where increased $\mathrm{Ca}^{2+}$ cycling serves as an adaptive mechanism to sustain cardiac pumping function, is observed subsequent to several perturbations of the heart.

The kinetics of mitochondrial $\mathrm{Ca}^{2+}$ uptake are uncertain, but the results of many studies indicate microdomains with close proximity between mitochondria and $\mathrm{SR} \mathrm{Ca}^{2+}$ release sites where a fast mitochondrial $\mathrm{Ca}^{2+}$ uptake may occur (25). Mitochondrial $\mathrm{Ca}^{2+}$ uptake may then act as a buffer and reduce the size of cytosolic $\mathrm{Ca}^{2+}$ transients (25). Compared to controls, cardiomyocytes of Mterf3 $\mathrm{KO}$ mice have a markedly higher mitochondrial content (31) and their mitochondrial $\mathrm{Ca}^{2+}$ uptake may then be larger, which would tend to decrease the size of cytosolic $\mathrm{Ca}^{2+}$ transients. In this study, we did not measure mitochondrial $\mathrm{Ca}^{2+}$, but our results show larger and faster $\mathrm{Ca}^{2+}$ transients in Mterf3 $\mathrm{KO}$ cardiomycytes as compared to controls. Thus, if an increased mitochondrial $\mathrm{Ca}^{2+}$ uptake were present in Mterf3 $\mathrm{KO}$ cardiomycytes, this was not large enough to counteract other factors acting towards increased $\mathrm{Ca}^{2+}$ transients.

Increased SR $\mathrm{Ca}^{2+}$ load and cycling is beneficial for improving the contractile performance. However, elevated SR 
$\mathrm{Ca}^{2+}$ load can trigger spontaneous $\mathrm{Ca}^{2+}$ release events through increased opening of the SR $\mathrm{Ca}^{2+}$ release channels, which can lead to triggered arrhythmias and thereby a risk of offsetting the benefits of increased contractility $(10,35,51)$. In this context, the positive effects of enhanced $\mathrm{Ca}^{2+}$ release and inotropy in the Mterf3 $\mathrm{KO}$ cardiomyocytes are accompanied by a high prevalence of spontaneous $\mathrm{Ca}^{2+}$ release events.

Stimulation of $\beta$-adrenergic receptors through increased drive of the sympathetic nervous system is the principal signaling to elicit increased $\mathrm{Ca}^{2+}$ cycling and inotropy (4). It is therefore assumed that the increased sympathetic drive commonly found in humans as well as in animal models of cardiomyopathy and heart failure (manifested as higher levels of catecholamines in the blood and decreased heart rate variability) constitutes the key signal by which the organism tries to compensate for the failing cardiac output. Chronic increase in sympathetic drive can, however, aggravate the cardiomyopathy phenotype and show strong correlation with premature mortality and sudden cardiac death in heart failure $(8,9$, 28). In the Mterf3 KO mice, we found evidence of elevated sympathetic signaling in the pre-moribund stage, indicated by cardiomyocytes showing a decreased response to ISO and an increased RyR2 Ser ${ }^{2808}$ phosphorylation (see Fig. 2) and by drastically reduced heart rate variability (see Fig. 4D). Moreover, spectral analysis of the heart rate variability revealed a collapsed LF power spectrum and a low LF/HF ratio (see Fig. $4 \mathrm{E}$ ). In normal physiology, an increased sympathetic drive is sometimes associated with elevated LF and reduced HF components (41). However, in cardiac failure, the markedly excited sympathetic drive is typically followed by a dramatic decrease in LF power spectrum $(19,46)$. These data are, thus, consistent with a picture of chronic adrenergic stress in Mterf3 $\mathrm{KO}$ mice.

Morphological remodeling of the heart and cardiomyocytes, which occurs in cardiac hypertrophic diseases, is another phenomenon that poses restraints on cardiac contractile function (27). Mterf3 KO mice display cardiac hypertrophy (31) with increased width and length of cardiomyocytes (Fig. 2E). Cardiac failure is sometimes associated with alterations in transverse tubular structure. This may affect $\mathrm{Ca}^{2+}$ release synchrony, due to reduced juxtaposition between L-type $\mathrm{Ca}^{2+}$ channels and RyR, resulting in slowed $\mathrm{Ca}^{2+}$ transients (24). However, in Mterf3 $\mathrm{KO}$ cardiomyocytes, pacing-induced $\mathrm{Ca}^{2+}$ transients are larger and faster and the initiation of $\mathrm{Ca}^{2+}$ release is synchronous, even in cells showing aberrant $\mathrm{Ca}^{2+}$ releases (see Fig. 3), which speaks against adverse alterations in transverse tubular structure.

During the moribund stage, the Mterf3 $\mathrm{KO}$ mice show a progressive bradycardia due to an increasing AV conduction time and a terminal complete AV-block (Fig. 5). AV-block in mitochondrial cardiomyopathy is part of the features seen in the Kearns-Sayre syndrome $(2,22)$. In the cardiac respiratory chain-deficient Tfam $\mathrm{KO}$ mice, heart enlargement and ventricular dilatation was coupled with AV-block (48). Moreover, AV-block is described in cardiomyopathies of other types than primary mitochondrial cardiomyopathy $(7,32)$. The role of mitochondria in the cellular mechanisms underlying AV-block is elusive. However, the presence of AV-block in experimental models of mitochondrial cardiomyopathy, such as the Mterf3 $\mathrm{KO}$ and the Tfam KO (48) as well as in patients with mitochondrial disease $(2,22)$, suggests a role of the mitochondria in the cellular mechanisms of AV-block.

In conclusion, we show that mitochondrial dysfunction can lead to cardiomyopathy with a complex arrhythmogenic phenotype with spontaneous $\mathrm{Ca}^{2+}$ release events occurring at the level of the cardiomyocyte and terminal conduction system defects causing AV-block. These phenomena appear in the context of increased adrenergic signaling and enhanced cardiomyocyte $\mathrm{Ca}^{2+}$ cycling. This highlights the role of mitochondria in the early phase of cardiomyopathic disease, characterized by activation of adrenergic signaling and elevated risk of premature death.

\section{Materials and Methods}

\section{Animals}

Mice with tissue-specific ablation of Mterf3 the Mterf ${ }^{\text {loxP/loxP }} ;+/$ Ckmm-cre (Mterf3 KO), and littermate controls Mterf $3^{\text {loxP/loxP }}$ (control) were generated as described elsewhere (31). Mice were killed by cervical dislocation, and hearts excised. The investigation conforms to the Guide for the Care and Use of Laboratory Animals published by the US National Institutes of Health (NIH Publication No. 85-23, revised 1996). All animal experiments were approved by the Stockholm North and South local animal ethics committees.

\section{Cardiomyocyte isolation}

Isolation of cardiomyocytes was done according to protocols of the Alliance for Cellular Signalling (AfCS Procedure Protocol ID PP00000 125) (34) and has been described elsewhere (42). Cardiomyocytes were isolated from $\sim 14$-weekold Mterf3 $\mathrm{KO}$ and control mice. Cardiomyocytes were loaded with fluorescent indicators (see below) and placed on laminincoated coverslips that made up the bottom of the perfusion chamber. Cells were allowed to attach to the coverslip for $\sim 5 \mathrm{~min}$ before the start of experiments. The cells were then superfused with Tyrode solution (in $\mathrm{mM}$ ): $121 \mathrm{NaCl}, 5.0 \mathrm{KCl}$, $1.8 \mathrm{CaCl}_{2}, 0.5 \mathrm{MgCl}_{2}, 0.4 \mathrm{NaH}_{2} \mathrm{PO}_{4}, 24 \mathrm{NaHCO}_{3}, 0.1$ EDTA, and 5.5 glucose. The Tyrode solution was bubbled with $5 \%$ $\mathrm{CO}_{2} / 95 \% \mathrm{O}_{2}$, which gives a bath $\mathrm{pH}$ of 7.4 , and experiments were performed at room temperature $\left(\sim 24^{\circ} \mathrm{C}\right)$. Cells were continuously stimulated at $0.5 \mathrm{~Hz}, 1 \mathrm{~Hz}$, or $3 \mathrm{~Hz}$ with $1-\mathrm{ms}$ current pulses delivered via two platinum electrodes, one on each side of the perfusion chamber. Measurements were only performed on rod-shaped cells that displayed a uniform contraction in response to each stimulation pulse and showed no spontaneous contractile activity.

\section{Confocal imaging of cytoplasmic $\mathrm{Ca}^{2+}$ and shortening in isolated cardiomyocytes}

Confocal microscopy was performed using a Bio-Rad (Hercules, CA) MRC 1024 unit attached to a Nikon Diaphot inverted microscope with a Nikon Plan Apo 40x oil immersion objective (NA 1.3) (14). Cytoplasmic $\mathrm{Ca}^{2+}$ in isolated cardiomyocytes was measured with the fluorescent $\mathrm{Ca}^{2+}$ indicator fluo-3 and confocal images were obtained by line scanning along the long axis. Images were analyzed off line with ImageJ (National Institutes of Health [available at http:// rsb.info.nih.gov/ij; accessed April 7, 2011]). To enable comparisons between cells, changes in the fluo-3 fluorescence signal $(\Delta F)$ were divided by the fluorescence immediately before a stimulation pulse was given under control conditions $\left(F_{0}\right)$. The decay of the $\mathrm{Ca}^{2+}$ transients was assessed by measuring the time constant $(\tau)$ of the exponential part of the decay phase, ignoring the initial phase that often diverges 
from a monoexponential function (11). Cell shortening was determined simultaneously with measurements of $\mathrm{Ca}^{2+}$ by following the edges of the fluorescence images of the cells during contractions. The cell length was measured in the rested state and the maximally contracted state, and fractional shortening (FS\%) was defined as: ((relaxed cell length - contracted cell length) /(relaxed cell length) $)^{*} 100$. Measurements of $\mathrm{Ca}^{2+}$ transients and cell shortening on exposure to the $\beta$-adrenergic agonist isoproterenol (ISO; $100 \mathrm{nM}$ ) were done within 4-10 min after application of the drug. Presence of spontaneous $\mathrm{Ca}^{2+}$ events during line scan was defined as either: 1 ) the presence of at least one spontaneously activated "aberrant" $\mathrm{Ca}^{2+}$ transient; 2) $>5$ localized increases in fluorescence that is larger than 2 standard deviations of the surrounding fluorescence at the same time point. Line scans that displayed spontaneous $\mathrm{Ca}^{2+}$ events was not included in the measurements of $\mathrm{Ca}^{2+}$ transient amplitude and decay, or cell shortening.

\section{Confocal imaging of mitochondrial ROS production}

Changes in mitochondrial $\mathrm{O}_{2}{ }^{*-}$ production were monitored using MitoSOX Red (Invitrogen/Molecular Probes, Eugene, OR) (14). Isolated cardiomyocytes were incubated with $\mathrm{Mi}$ toSOX Red $(5 \mu \mathrm{M})$ for $30 \mathrm{~min}$ at room temperature and experiments started after $5 \mathrm{~min}$ of washing. MitoSOX Red was excited at $488 \mathrm{~nm}$ and emitted light collected through a $585 \mathrm{~nm}$ long-pass filter. A confocal image of cardiomyocytes at rest was obtained to get a starting point of MitoSOX Red fluorescence. Thereafter, myocytes were continuously paced at $1 \mathrm{~Hz}$ and images were taken. After $15 \mathrm{~min}$ of pacing, $1 \mathrm{mM}$ $\mathrm{H}_{2} \mathrm{O}_{2}$ was applied to induce product inhibition of superoxide dismutase 2 (SOD2) $(17,29)$ and fluorescence was measured at regular intervals for as long as the cardiomyocyte was viable. The fluorescent signal at all time points was normalized to the signal at the starting point.

\section{Confocal imaging of mitochondrial membrane potential}

Tetramethylrhodamine ethyl ester (TMRE; Invitrogen/ Molecular Probes) was used to measure mitochondrial membrane potential $\left(\Delta \Psi_{\mathrm{m}}\right)(12,14)$. Isolated cardiomyocytes were loaded with $10 \mathrm{nM}$ TMRE for $15 \mathrm{~min}$ at room temperature, followed by washout. Confocal images of TMRE fluorescence were obtained by excitation at $568 \mathrm{~nm}$ while measuring the emitted light at $585 \mathrm{~nm}$. The cells were continuously stimulated at $1 \mathrm{~Hz}$. Images were taken every 2-3 min. After $15 \mathrm{~min}$, cells were exposed to the mitochondrial uncoupler carbonyl cyanide 4-(trifluoromethoxy)phenylhydrazone (FCCP) $(1 \mu M)$ to determine the dynamic range of the dye. Measurements were done in the same cell regions at each time point. Fluorescence signals obtained from mitochondria-rich areas were divided by fluorescence from an adjacent cytosolic region. The ratio thereby obtained for each time point was normalized to the point where the mitochondrial depolarizing effect of FCCP reached its maximum.

\section{Northern blot analysis on SOD2 mRNA expression}

RNA from hearts of $\sim 12$-week-old Mterf3 $\mathrm{KO}$ and control mice was isolated using the TRIzol Reagent (Invitrogen/GIBCO-BRL Life Technologies). DNA probes specific to the genes of interest were labeled with $\left[\alpha_{-}{ }^{32} \mathrm{P}\right]-\mathrm{dCTP}$ by using random primer extension method. Phosphorimager analysis of Northern blots was used to assess levels of transcripts in comparison to the nuclear $18 \mathrm{~S}$ rRNA levels as described previously (39).

\section{Aconitase and citrate synthase activity}

Measurements of aconitase activity was performed using isolated mitochondria from hearts of 12-16-week-old Mterf3 $\mathrm{KO}$ and control mice according to a protocol described elsewhere (15). The activity of aconitase was normalized to the total protein content in the sample. Aconitase was also normalized to the citrate synthase (CS) activity and given the unit: $\mathrm{mU}$ aconitase activity/U CS activity (mU/U). CS activity was measured from the same sample (50).

\section{Western blot analysis}

Hearts of $\sim 12$-week-old mice were homogenized in icecold homogenization buffer $\mathrm{pH} 7.4(20 \mu \mathrm{l}$ per mg wet weight $)$ consisting of (mM): $20 \mathrm{HEPES}, 150 \mathrm{NaCl}, 5 \mathrm{EDTA}, 25 \mathrm{KF}$, $1 \mathrm{Na}_{3} \mathrm{VO}_{4} ; 20 \%$ glycerol, $0.5 \%$ Triton $\mathrm{X}$, protease inhibitor cocktail (Roche, Basel, Switzerland) 1 tablet $/ 50 \mathrm{ml}$. The homogenate was centrifuged at $3000 \mathrm{~g}$ for $10 \mathrm{~min}$ at $4^{\circ} \mathrm{C}$. Samples were diluted 1:2 in Laemmli buffer (Bio-Rad); for ryanodine receptor (RyR) and SOD2 analyses, samples were heated to $70^{\circ} \mathrm{C} 10 \mathrm{~min} .30 \mu \mathrm{g}$ were then loaded into each well and separated by electrophoresis using NuPAGE Novex $4 \%-12 \%$ BisTris Gels (Invitrogen) and transferred onto polyvinylidine fluoride membranes (Immobilon FL, Millipore, Billerica, MA). Membranes were blocked for 1 hour at room temperature in LI-COR blocking buffer (LI-COR Biosciences, Lincoln, $\mathrm{NE}$ ) and incubated with antibodies overnight at $4{ }^{\circ} \mathrm{C}$. All antibodies were diluted in blocking buffer and the following antibodies and dilutions were used: anti-phosphoRyR2-pSer ${ }^{2808}$ 1:2500 (gift from Andrew Marks, Columbia University College of Physicians \& Surgeons, NY), anti-RyR2 total 1:1000 (5029, gift from Andrew Marks), anti-SOD2 1:1000 (06-984, Upstate, Lake Placid, NY), anti-malondialdehyde (MDA) 1:500 (MD20A-R1a, Academy Bio-Medical, Houston, TX). RyR2(pho-Ser2809) was stripped by incubating in $50 \mathrm{mM}$ TrisBase, SDS $2 \%$, pH 6.8 at $60^{\circ} \mathrm{C}$ for $40 \mathrm{~min}$ before incubating with anti-RyR total. Membranes were then washed $3 X 5 \mathrm{~min}$ in TBS-T and incubated for $1 \mathrm{~h}$ at room temperature with IRDye 680 conjugated goat anti-mouse IgG and IRDye 800 conjugated goat anti-mouse IgG (1:15000, LI-COR) diluted in LI-COR blocking buffer with $0.01 \%$ SDS and $0.005 \%$ Tween 20 . Finally, membranes were washed for 4 X $10 \mathrm{~min}$ in TBS-T. Immunoreactive bands were visualized using infrared fluorescence (IR-Odyssey scanner, LI-COR Biosciences) densitometric quantifications of band intensities were done using ImageJ (National Institutes of Health [available at http://rsb.info .nih.gov/ij]). Membranes were later stained with SimplyBlue Safe stain (Invitrogen) to assess protein loading of each well.

\section{Telemetric ECG recordings}

ECG, core body temperature, and locomotor activity recordings were performed on conscious, freely moving individually caged $\sim 14$-week-old Mterf3 $\mathrm{KO}(n=3)$ and control mice $(n=3)(18)$. The telemetry transmitter-receiver system (TA10ETA-F20; RPC-1) was connected to a data acquisition system (Data Science International, St. Paul, MN). Data were collected continuously $(24 \mathrm{~h} /$ day) at a sampling rate of $1000 \mathrm{~Hz}$ until the endpoint in the Mterf $3 \mathrm{KO}$ and for 14 days in the 
control. Transmitters were implanted in the abdominal cavity during isoflurane anesthesia ( $\sim 20 \mathrm{~min})$. Two ECG electrodes were placed subcutaneously, one at the right shoulder (negative) and the other in the lower left chest region (positive) approximating the Einthoven lead II (20). ECG recordings were analyzed off line with the software ECG-auto (version 1.5.12.22, EMKA Technologies, Paris, France). The telemetric data were analyzed as described previously $(43,44)$.

\section{Analysis of ECG recordings}

ECG signals were digitally pass filtered between 0.1 and $1000 \mathrm{~Hz}$ and then analyzed during the night time period. R-R, $\mathrm{P}-\mathrm{R}$, and QRS intervals were calculated from 5 days prior to the endpoint of the Mterf3 $\mathrm{KO}$ and compared to results obtained during the same period in the control. On the same records, heart rate variability (HRV) was calculated from the $R-R$ values. The standard deviation of all normal R-R intervals (SDNN) was used as the measure for HRV. Moreover, power spectral analysis of the HRV was performed. One ECG period of $3 \mathrm{~min}$ was selected every $2 \mathrm{~h}$ during a period of low locomotor activity. The power spectra analysis was done using the fast Fourier transform (segment length 2048 beats, linear interpolation with re-sampling to a $20-\mathrm{Hz}$ interbeat time series and Hamming windowing). The frequency range was divided into a low-frequency (LF) range $(0.15-1.5 \mathrm{~Hz})$ and a high-frequency $(\mathrm{HF})$ range $(1.5-5 \mathrm{~Hz})(43,44)$.

\section{Statistics}

For comparisons between two independent data groups, unpaired Student's $t$-test was used. When more than two groups were compared, analysis of variance (ANOVA) was used, followed by an appropriate post hoc test. Significance level was set to $P<0.05$. SigmaStat (version 3.1, Systat Software, Point Richmond, CA) was used for statistical computations. Data are expressed as average \pm standard error of the mean (SEM) unless stated otherwise.

\section{Acknowledgments}

We thank Professor Anders Arner and Dr. Rolf Wibom for valuable technical assistance. Whole animal physiology experiments were performed in the Genetic Physiology Core Facility at Karolinska Institutet. Funds from the following sources were used to support this work: Swedish Heart Lung Foundation; Swedish Research Council; Lars Hierta Memorial Foundation; Sigurd och Elsa Goljes Memorial Foundation; Association Française contre les Myopathies (AFM), and Funds at the Karolinska Institute.

\section{Author Disclosure Statement}

No competing financial interests exist.

\section{References}

1. Aldini G, Dalle-Donne I, Facino RM, Milzani A, and Carini M. Intervention strategies to inhibit protein carbonylation by lipoxidation-derived reactive carbonyls. Med Res Rev 27: 817-868, 2007.

2. Anan R, Nakagawa M, Miyata M, Higuchi I, Nakao S, Suehara M, Osame M, and Tanaka H. Cardiac involvement in mitochondrial diseases. A study on 17 patients with documented mitochondrial DNA defects. Circulation 91: 955-961, 1995.

3. Aydin J, Andersson DC, Hanninen SL, Wredenberg A, Tavi P, Park CB, Larsson NG, Bruton JD, and Westerblad H. Increased mitochondrial $\mathrm{Ca}^{2+}$ and decreased sarcoplasmic reticulum $\mathrm{Ca}^{2+}$ in mitochondrial myopathy. Human Mol Genet 18: 278-288, 2009.

4. Bers DM. Cardiac excitation-contraction coupling. Nature 415: 198-205, 2002.

5. Bers DM. Altered cardiac myocyte Ca regulation in heart failure. Physiology (Bethesda) 21: 380-387, 2006.

6. Bristow MR, Ginsburg R, Minobe W, Cubicciotti RS, Sageman WS, Lurie K, Billingham ME, Harrison DC, and Stinson EB. Decreased catecholamine sensitivity and betaadrenergic-receptor density in failing human hearts. New Engl J Med 307: 205-211, 1982.

7. Cicek D, Camsari A, and Doven O. Familial hypertrophic cardiomyopathy complicated by complete atrioventricular block. Acta Cardiol 59: 71-74, 2004.

8. Clark AL, and Cleland JG. The control of adrenergic function in heart failure: Therapeutic intervention. Heart Fail Rev 5: 101-114, 2000.

9. Curran J, Hinton MJ, Rios E, Bers DM, and Shannon TR. Betaadrenergic enhancement of sarcoplasmic reticulum calcium leak in cardiac myocytes is mediated by calcium/calmodulindependent protein kinase. Circ Res 100: 391-398, 2007.

10. Diaz ME, Graham HK, O'Neill SC, Trafford AW, and Eisner DA. The control of sarcoplasmic reticulum Ca content in cardiac muscle. Cell Calcium 38: 391-396, 2005.

11. Diaz ME, Trafford AW, and Eisner DA. The role of intracellular Ca buffers in determining the shape of the systolic Ca transient in cardiac ventricular myocytes. Pflügers Arch 442: 96-100, 2001.

12. Duchen MR, Leyssens A, and Crompton M. Transient mitochondrial depolarizations reflect focal sarcoplasmic reticular calcium release in single rat cardiomyocytes. J Cell Biol 142: 975-988, 1998.

13. Esposito LA, Melov S, Panov A, Cottrell BA, and Wallace DC. Mitochondrial disease in mouse results in increased oxidative stress. Proc Natl Acad Sci USA 96: 4820-4825, 1999.

14. Fauconnier J, Andersson DC, Zhang SJ, Lanner JT, Wibom R, Katz A, Bruton JD, and Westerblad H. Effects of palmitate on $\mathrm{Ca}^{2+}$ handling in adult control and $\mathrm{ob} / \mathrm{ob}$ cardiomyocytes: Impact of mitochondrial reactive oxygen species. Diabetes 56: 1136-1142, 2007.

15. Gardner PR. Aconitase: Sensitive target and measure of superoxide. Methods Enzymol 349: 9-23, 2002.

16. Gwathmey JK, Copelas L, MacKinnon R, Schoen FJ, Feldman MD, Grossman W, and Morgan JP. Abnormal intracellular calcium handling in myocardium from patients with end-stage heart failure. Circ Res 61: 70-76, 1987.

17. Hearn AS, Tu C, Nick HS, and Silverman DN. Characterization of the product-inhibited complex in catalysis by human manganese superoxide dismutase. J Biol Chem 274: 24457-24460, 1999.

18. Johansson $C$ and Thoren $P$. The effects of triiodothyronine $\left(T_{3}\right)$ on heart rate, temperature and ECG measured with telemetry in freely moving mice. Acta Physiol Scand 160: 133-138, 1997.

19. Kienzle MG, Ferguson DW, Birkett CL, Myers GA, Berg WJ, and Mariano DJ. Clinical, hemodynamic and sympathetic neural correlates of heart rate variability in congestive heart failure. Am J Cardiol 69: 761-767, 1992.

20. Kramer K, van Acker SA, Voss HP, Grimbergen JA, van der Vijgh WJ, and Bast A. Use of telemetry to record electro- 
cardiogram and heart rate in freely moving mice. J Pharmacol Toxicol Methods 30: 209-215, 1993.

21. Kujoth GC, Hiona A, Pugh TD, Someya S, Panzer K, Wohlgemuth SE, Hofer T, Seo AY, Sullivan R, Jobling WA, Morrow JD, Van Remmen H, Sedivy JM, Yamasoba T, Tanokura $\mathrm{M}$, Weindruch $\mathrm{R}$, Leeuwenburgh $\mathrm{C}$, and Prolla TA. Mitochondrial DNA mutations, oxidative stress, and apoptosis in mammalian aging. Science 309: 481-484, 2005.

22. Larsson NG and Oldfors A. Mitochondrial myopathies. Acta Physiol Scand 171: 385-393, 2001.

23. Litwin SE, Zhang D, and Bridge JH. Dyssynchronous $\mathrm{Ca}^{2+}$ sparks in myocytes from infarcted hearts. Circ Res 87: 10401047, 2000

24. Louch WE, Sejersted OM, and Swift F. There goes the neighborhood: Pathological alterations in T-tubule morphology and consequences for cardiomyocyte $\mathrm{Ca}^{2+}$ handling. J Biomed Biotechnol 2010: 503906, 2010.

25. Maack $C$ and $O^{\prime}$ Rourke B. Excitation-contraction coupling and mitochondrial energetics. Basic Res Cardiol 102: 369-392, 2007.

26. Marin-Garcia J and Goldenthal MJ. Mitochondrial centrality in heart failure. Heart Fail Rev 13: 137-150, 2008

27. Maron BJ. Hypertrophic cardiomyopathy. Lancet 350: 127133, 1997.

28. Marx SO, Reiken S, Hisamatsu Y, Jayaraman T, Burkhoff D, Rosemblit N, and Marks AR. PKA phosphorylation dissociates FKBP12.6 from the calcium release channel (ryanodine receptor) Defective regulation in failing hearts. Cell 101: 365-376, 2000.

29. McAdam ME, Levelle F, Fox RA, and Fielden EM. A pulseradiolysis study of the manganese-containing superoxide dismutase from Bacillus stearothermophilus. Biochem J 165: 8187, 1977.

30. Mørk HK, Sjaastad I, Sande JB, Periasamy M, Sejersted OM, and Louch WE. Increased cardiomyocyte function and $\mathrm{Ca}^{2+}$ transients in mice during early congestive heart failure. $\mathrm{J} \mathrm{Mol}$ Cell Cardiol 43: 177-186, 2007.

31. Park CB, Asin-Cayuela J, Camara Y, Shi Y, Pellegrini M, Gaspari M, Wibom R, Hultenby K, Erdjument-Bromage H, Tempst P, Falkenberg M, Gustafsson CM, and Larsson NG. MTERF3 is a negative regulator of mammalian mtDNA transcription. Cell 130: 273-285, 2007.

32. Rosen KL, Cameron RW, Bigham PJ, and Neish SR. Hypertrophic cardiomyopathy presenting with 3rd-degree atrioventricular block. Tex Heart Inst J 24: 372-375, 1997.

33. Rossignol R, Letellier T, Malgat M, Rocher C, and Mazat JP. Tissue variation in the control of oxidative phosphorylation: Implication for mitochondrial diseases. Biochem J 347: 45-53, 2000.

34. Sambrano GR, Fraser I, Han H, Ni Y, O'Connell T, Yan Z, and Stull JT. Navigating the signalling network in mouse cardiac myocytes. Nature 420: 712-714, 2002.

35. Satoh H, Blatter LA, and Bers DM. Effects of $\left[\mathrm{Ca}^{2+}\right]_{i}, \mathrm{SR}$ $\mathrm{Ca}^{2+}$ load, and rest on $\mathrm{Ca}^{2+}$ spark frequency in ventricular myocytes. Am J Physiol 272: H657-H668, 1997.

36. Shan J, Kushnir A, Betzenhauser MJ, Reiken S, Li J, Lehnart SE, Lindegger N, Mongillo M, Mohler PJ, and Marks AR. Phosphorylation of the ryanodine receptor mediates the cardiac fight or flight response in mice. J Clin Invest 120: 4388-4398, 2010.

37. Shannon TR and Bers DM. Integrated $\mathrm{Ca}^{2+}$ management in cardiac myocytes. Ann NY Acad Sci 1015: 28-38, 2004.

38. Smeitink J, van den HL, and DiMauro S. The genetics and pathology of oxidative phosphorylation. Nat Rev Genet 2: 342-352, 2001

39. Sörensen L, Ekstrand M, Silva JP, Lindqvist E, Xu B, Rustin $\mathrm{P}$, Olson L, and Larsson NG. Late-onset corticohippocampal neurodepletion attributable to catastrophic failure of oxidative phosphorylation in MILON mice. J Neurosci 21: 80828090, 2001

40. St Pierre J, Drori S, Uldry M, Silvaggi JM, Rhee J, Jager S, Handschin C, Zheng K, Lin J, Yang W, Simon DK, Bachoo R, and Spiegelman BM. Suppression of reactive oxygen species and neurodegeneration by the PGC-1 transcriptional coactivators. Cell 127: 397-408, 2006.

41. Task Force of the European Society of C. Heart rate variability. Standards of measurement, physiological interpretation, and clinical use. Eur Heart J 17: 354-381, 1996.

42. Tavi P, Hansson A, Zhang SJ, Larsson NG, and Westerblad H. Abnormal $\mathrm{Ca}^{2+}$ release and catecholamine-induced arrhythmias in mitochondrial cardiomyopathy. Hum Mol Genet 14: 1069-1076, 2005.

43. Thireau J, Poisson D, Zhang BL, Gillet L, Le Pecheur M, Andres C, London J, and Babuty D. Increased heart rate variability in mice overexpressing the $\mathrm{Cu} / \mathrm{Zn}$ superoxide dismutase. Free Radic Biol Med 45: 396-403, 2008.

44. Thireau J, Zhang BL, Poisson D, and Babuty D. Heart rate variability in mice: A theoretical and practical guide. Exp Physiol 93: 83-94, 2008.

45. Trifunovic A, Wredenberg A, Falkenberg M, Spelbrink JN, Rovio AT, Bruder CE, Bohlooly Y, Gidlof S, Oldfors A, Wibom R, Tornell J, Jacobs HT, and Larsson NG. Premature ageing in mice expressing defective mitochondrial DNA polymerase. Nature 429: 417-423, 2004.

46. van de Borne P, Montano N, Pagani M, Oren R, and Somers VK. Absence of low-frequency variability of sympathetic nerve activity in severe heart failure. Circulation 95: 1449-1454, 1997.

47. Wallace DC. A mitochondrial paradigm of metabolic and degenerative diseases, aging, and cancer: A dawn for evolutionary medicine. Annu Rev Genet 39: 359-407, 2005.

48. Wang J, Wilhelmsson H, Graff C, Li H, Oldfors A, Rustin P, Bruning JC, Kahn CR, Clayton DA, Barsh GS, Thoren P, and Larsson NG. Dilated cardiomyopathy and atrioventricular conduction blocks induced by heart-specific inactivation of mitochondrial DNA gene expression. Nat Genet 21: 133-137, 1999.

49. Wehrens XH, Lehnart SE, and Marks AR. Intracellular calcium release and cardiac disease. Annu Rev Physiol 67: 69-98, 2005.

50. Wibom R, Hagenfeldt L, and von Döbeln U. Measurement of ATP production and respiratory chain enzyme activities in mitochondria isolated from small muscle biopsy samples. Anal Biochem 311: 139-151, 2002.

51. Yuan Q, Fan GC, Dong M, Altschafl B, Diwan A, Ren X, Hahn HH, Zhao W, Waggoner JR, Jones LR, Jones WK, Bers DM, Dorn GW, Wang HS, Valdivia HH, Chu G, and Kranias EG. Sarcoplasmic reticulum calcium overloading in junctin deficiency enhances cardiac contractility but increases ventricular automaticity. Circulation 115: 300-309, 2007.

Address correspondence to: Prof. Håkan Westerblad Department of Physiology and Pharmacology Karolinska Institute von Eulers vag 8 SE-171 77 Stockholm Sweden

E-mail: hakan.westerblad@ki.se 


Abbreviations Used
$\Delta \Psi_{\mathrm{m}}=$ mitochondrial membrane potential
$\mathrm{ANOVA}=$ analysis of variance
$\mathrm{AV}-\mathrm{block}=$ atrioventricular conduction block
$\mathrm{CS}=$ citrate synthase
$\mathrm{ECG}=$ electrocardiography
$\mathrm{FCCP}=$ carbonyl cyanide 4 -(trifluoromethoxy)
phenylhydrazone
$\mathrm{FS}=$ fractional shortening
$\mathrm{HF}=$ high-frequency
$\mathrm{HRV}=$ heart rate variability
$\mathrm{ISO}=$ isoproterenol
$\mathrm{LF}=$ low-frequency
$\mathrm{MDA}=$ malondialdehyde

mtDNA $=$ mitochondrial DNA

MTERF3 = mitochondrial transcription termination factor 3

POLRMT $=$ mitochondrial RNA polymerase

$\mathrm{ROS}=$ reactive oxygen species

$\mathrm{RyR}=$ ryanodine receptor

SDNN $=$ standard deviation of all normal R-R intervals

$\mathrm{SEM}=$ standard error of the mean

$\mathrm{SOD}=$ superoxide dismutase

$\mathrm{SR}=$ sarcoplasmic reticulum

Tfam $=$ mitochondrial transcription factor $\mathrm{A}$

TFB1M $=$ mitochondrial transcription factor B1

TFB2M = mitochondrial transcription factor B2

TMRE $=$ tetramethylrhodamine ethyl ester 